\title{
Effects of Dietary Supplements of Wheat Bran and Cellulose on Faeces and Bowel Function
}

\author{
M. A. EASTWOOD, J. R. KIRKPATRICK, W. D. MITCHELL, ANN BONE, T. HAMILTON
}

British Medical fournal, 1973, 4, 392-394

\section{Summary}

In a study of bowel function in normal subjects wheat bran or cellulose was added to the diet for four weeks (16 g/day). Stool weight increased. Intestinal transit time did not significantly alter. Faecal bile acids did not increase but were diluted. It seems that the effect of these materials is to produce a bulky stool and that any symptomatic benefit they produce is secondary to this.

\section{Introduction}

In recent years epidemiological evidence has suggested that a reduction in dietary "fibre" and "roughage" is of aetiological significance in certain diseases to which Western man has increasingly become a victim (Burkitt, 1971). As a consequence of these studies "high roughage diets" have been advocated for the prevention and the management of diverticular disease of the colon. Putting the epidemiological evidence to experimental test, however, is difficult because of the long-term nature of the potential effects. This present preliminary study was designed to measure the short-term effects, if any, on bowel habit and faecal constituents of the addition of wheat bran and cellulose to a normal diet.

\section{Subjects and Methods}

The studies were conducted on healthy males, age range $25-43$ years, when they were leading their normal lives as physicians, surgeons, and medical students.

The following experiments were carried out.

Experiment $A$ comprised eight subjects who completed the following programme: (1) a control period of one week on their usual diet (Control 1); and (2) a three-week period with a similar diet supplemented by $8 \mathrm{~g}$ of wheat bran twice a aay.

Experiment B.-Four of the subjects completed the following programme: periods (1) and (2) were as described for experiment A (Control 1 and bran); (3) a further three-week control period (Control 2); and (4) a three-week period with a dietary supplement of Whatman's chromatography cellulose (CF1) $8 \mathrm{~g}$ twice a day.

Investigations.-In each experiment the following information was obtained during the final seven days of each period: (1) body weight; (2) a daily weighed record of all food and fluid intake. Fibre intake was estimated from tables (Documenta Geigy, $1962)$; (3) the time of defaecation was recorded for each stool, which was collected separately in a plastic bag and stored at

University of Edinburgh Gastrointestinal Unit, Western General Hospital, Edinburgh EH4 2XU

M. A. EASTWOOD, M.B., F.R.C.P., Consultant Physician

J. R. KIRKPATRICK, CH.M., F.R.C.S., Consultant Surgeon

W. D. MITCHELL, PH.D., A.R.I.C., Senior Biochemist

ANN BONE, Dietitian

T. HAMILTON, M.B., F.R.c.s., Consultant Surgeon $-20^{\circ} \mathrm{C}$ until analysed; (4) the intestinal transit time was measured with barium -40 impregnated pellets (Hinton et al., 1969) and was the time taken for recovery of more than $80 \%$ of the ingested pellets; (5) the stools collected over seven days were weighed (total wet weight), homogenized with an equal volume of water, and an aliquot was freeze dried (dry weight); (6) faecal bile acids excretion (Evrard and Janssen, 1968); and, (7) serum cholesterol was measured on three occasions in each week of study.

\section{Results}

EXPERIMENT A

The effect of bran supplement was as follows.

Weight of Stool.-The wet and dry weight of stool increased significantly after the ingestion of bran (table I). The most striking increase was in the wet weight (107 $\mathrm{g} \pm 44$ S.D. to $174 \mathrm{~g} \pm 51, \mathrm{P}<0.001)$. This was due to the increased water content of the stool. The average daily increase in dry weight was equivalent to the amount of bran ingested.

Transit Time.-No significant alteration in transit time occurred under the influence of bran (see graph).

Faecal Bile Acids. - No significant change in total faecal bile acid excretion occurred under the influence of bran. Because of the increased bulk of the stool, however, a significant diluent effect $(P<0.025)$ was observed in the concentration of faecal bile acids-wet faeces $2.06 \mathrm{mg} / \mathrm{g} \pm 1.3$ S.D. to $1.08 \mathrm{mg} / \mathrm{g} \pm 0.35$ : dry faeces $8.1 \mathrm{mg} / \mathrm{g} \pm 7.5$ to $4.9 \mathrm{mg} / \mathrm{g} \pm 1.9$ (table II).

Serum Cholesterol.-No change in serum cholesterol was observed, $186 \mathrm{mg} / 100 \mathrm{ml} \pm 27$ S.D. to $189 \mathrm{mg} / 100 \mathrm{ml} \pm 22$.

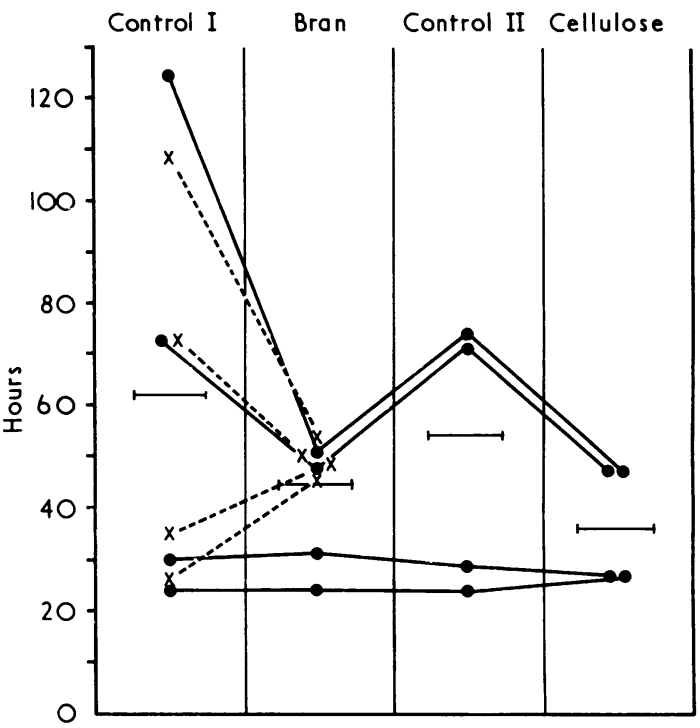

Intestinal transit times (mean and individual) in hours during each experimental period $X=$ Experiment $A$. $=$ Experiment $\mathrm{B}$. 
TABLE I-Mean Effect of Dietary Regimens ( \pm S.D.) on Faeces (g/day)

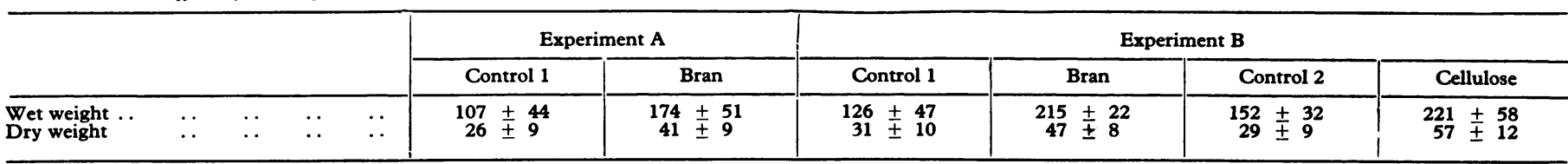

TABLE II-Mean Effect of Dietary Regimens ( \pm S.D.) on Bile Acid Metabolism (mg/day)

\begin{tabular}{|c|c|c|c|c|c|c|c|c|c|c|}
\hline \multirow{2}{*}{\multicolumn{5}{|c|}{ Faecal Bile Acids }} & \multicolumn{2}{|c|}{ Experiment A } & \multicolumn{4}{|c|}{ Experiment B } \\
\hline & & & & & Control 1 & Bran & Control 1 & Bran & Control 2 & Cellulose \\
\hline $\begin{array}{c}\text { Lithocholic acid } \\
\text { Deoxycholic acid } \\
\text { Total } \\
\text { Wet faeces (mg/g) } \\
\text { Dry faeces (mg/g) }\end{array}$ & $\begin{array}{l}. . \\
\because \\
\because \\
.\end{array}$ & $\begin{array}{l}\cdots \\
\cdots \\
\cdots\end{array}$ & $\begin{array}{l}\cdots \\
\because \\
\cdots\end{array}$ & $\begin{array}{l}\cdots \\
\cdots \\
\cdots \\
\cdots\end{array}$ & 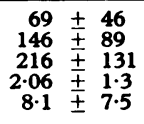 & $\begin{aligned} 64 & \pm 23 \\
143 & \pm 74 \\
207 & \pm 96 \\
1.08 & \pm 0.35 \\
4.9 & \pm 1.9\end{aligned}$ & $\begin{aligned} 95 & \pm 55 \\
203 & \pm 98 \\
299 & \pm 145 \\
2.6 & \pm 1.8 \\
11.8 & \pm 7.7\end{aligned}$ & $\begin{array}{ll}80.9 & \pm 18 \\
185 & \pm 83 \\
267 & \pm 99 \\
1.2 & \pm 0.41 \\
5.8 & \pm 2.2\end{array}$ & $\begin{array}{rl}117 & \pm 31 \\
275 & \pm \\
396 & 129 \\
2.8 & \pm 157 \\
14.2 & \pm 6.0\end{array}$ & $\begin{array}{rll}137 & \pm & 49 \\
341 & \pm & 198 \\
478 & \pm & 244 \\
2 \cdot 08 & \pm & 0.58 \\
8 \cdot 2 & \pm & 3 \cdot 1\end{array}$ \\
\hline
\end{tabular}

TABLE III-Details of Diet (Results expressed as Mean \pm S.D. for all Subjects Participating in Each Experiment)

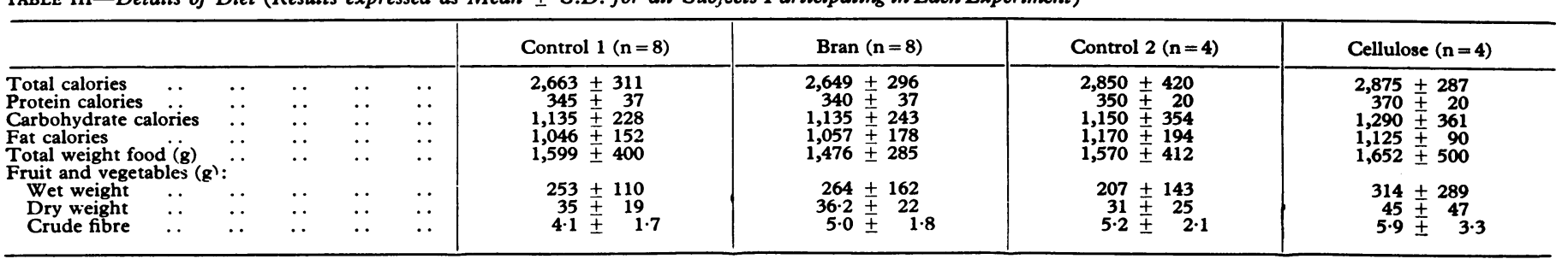

\section{EXPERIMENT B}

The four subjects in this part of the investigation were drawn from the eight who participated in experiment $A$. The effects of bran on stool weight, faecal bile acid output, and serum cholesterol in these four subjects were equivalent to those obtained in experiment A. The effects of cellulose were similar to those resulting from the ingestion of bran.

Weight of Stool.-There was an increase in the wet and dry weight of stool after the three-week period of taking ceilulose. The increase was in the water content of the stool (wet weight $152 \mathrm{~g} /$ day \pm 32 S.D. to $221 \mathrm{~g} /$ day $\pm 58, \mathrm{P}<0.001$ ) (table I)

Transit Time.-No significant alteration in intestinal transit occurred.

Faecal Bile Acids.-There was no significant difference between the faecal bile acid excretion in control period 2 and after cellulose. There was a diluent effect on the faecal bile acids -dry faeces $14.2 \mathrm{mg} / \mathrm{g} \pm 6.0 \mathrm{~S} . \mathrm{D}$. to $8.2 \mathrm{mg} / \mathrm{g} \pm 3.1, \mathrm{P}<0.0256$ but it did not reach significance for wet faeces, $2.8 \mathrm{mg} / \mathrm{g} \pm 1.4$ to $2.08 \mathrm{mg} / \mathrm{g} \pm 0.58$ (table II). There was, however, a significant increase in the faecal bile acids between the bran period and control period 2, $267 \mathrm{mg} /$ day \pm 99 S.D. to $396 \mathrm{mg} /$ day \pm 157 , $P<0.005$. The concentration of faecal bile acids in control period 2 returned to values similar to control period 1 after the dilution effect of bran (table II).

Serum Cholesterol.-No change in serum cholesterol was observed throughout the study (186 mg/100 ml \pm 26 S.D.).

\section{COMMENT}

At the start of the experiment, during control period 1, there was a linear relation between the daily faecal bile acids and wet and dry weight of stool-that is, the larger the faecal output the greater the bile acid output. The number of results are too small for statistical significance. Because of the short duration of the experimental periods no conclusions could be reached about the influence of bran and cellulose on this relation.

The constituents of the faecal bile acid excretion expressed as deoxycholic and lithocholic acid are given in table II, though what is actually measured is the 3,12-diketocholanoic acid and 3-monoketocholanoic acid respectively. Changes in the excretion of both bile acids parallel the total bile acid excretion. The ratio of deoxycholic acid (derived from cholic acid) and lithocholic acid (derived from chenodeoxycholic acid) remained unchanged $(2 \cdot 5: 1)$.

All subjects maintained their appetite and weight. The total food intake and the constituents of the diet remained unchanged during the experiment for each subject (table III). Maximum variation from individual mean was $14 \%$. The gross and estimated dry weight of fruit and vegetables varied by as much as $33 \%$. The calculated fibre content, however, was constant.

\section{Discussion}

The most striking effect of both bran and cellulose on the faeces is a pronounced increase in stool weight which is largely accounted for by an increase in water content. The increase in faecal weight after ingestion of bran was also observed by Payler (1973). During both experimental periods all subjects experienced a subjective appreciation of increased bulk and softer consistency of the stool and a feeling of greater urgency of defaecation. These subjective impressions were not reflected by alteration of intestinal transit time, though subjects with long transit times had shorter transit times when given bran. A similar finding was reported by Harvey et al. (1973). The laxative effects of wheat bran were reported by Cowgill and Anderson (1932) whoalso concluded that they were due entirely to the hygroscopic nature of bran.

The only other significant changes occurred in the faecal bile acids. The faecal bile acids were diluted during the periods of enhanced stool output. The increase in faecal bile acid output during control period 2 was a surprise. The possibility that this is due to a delayed effect of the bran is under investigation. It is noteworthy, however, that during control period 1 there was a linear relation between the total bile acids excreted and the total weight of stool for the particular individual. The numbers 
are small, however, and a larger study would be necessary to confirm this observation.

It has been suggested that a high intake of fibre can cause increased faecal bile acid excretion and hence decrease serum cholesterol concentration (Trowell, 1972). However, all the evidence does not support this hypotkesis as is shown in the review by Cummings (1973). In this present study increased dietary fibre was not associated with any change in serum cholesterol concentration.

The association of dietary fibre and diverticular disease is relatively well established (Painter, 1968, 1969; Painter and Burkitt, 1971). It would appear from the results of the present study that the possible therapeutic effect of bran or cellulose in preventing or treating diverticular disease is largely due to the ability of these substances to increase stool bulk. From the data presented it is calculated that an $80-\mathrm{kg}$ man passing $100 \mathrm{~g}$ stool per day would excrete faeces equivalent to his body weight about every two years. By the ingestion of $16 \mathrm{~g}$ of bran or cellulose daily this output would be achieved in only 12 months.

Significant alteration in colonic work load, intestinal function, and, possibly, in susceptibility of the bowel to pathological processes may be achieved by relatively minor alterations in dietary habit.

This study would not have been possible but for the co-operation of Messrs. Morgan, Karakoulis, McNicol, and Wilson. We are grateful to Dr. I. W. Percy-Robb in the clinical chemistry department for serum cholesterol estimations.

\section{References}

Burkitt, D. P. (1971). Cancer, 28, 3.

Cowgill, G. R., and Anderson, W. E. (1932). Fournal of the American Medical Association, 98, 1866.

Cummings, J. H. (1973). Gut, 14, 69.

Documenta Geigy (1962). Scientific Tables, 6th edn.-(Geigy U.K.), Macclesfield, Ches.

Evrard, E., and Janssen, G. (1968). Fournal of Lipid Research, 9, 226.

Harvey, R. F., Pomare, E. W., and Heaton, K. W. (1973). Lancet, 1, 1278. Hinton, J. M., Lennard-Jones, J. E., and Young, A. C. (1969). Gut, 10, 842. Painter, N. S. (1968). British Medical fournal, 3, 475.

Painter, N. S. (1969). Lancet, 2, 586

Painter, N. S., and Burkitt, D. P. (1971). British Medical fournal, 2, 450. Payler, D. K. (1973). Lancet, 1, 1394.

Trowell, H. (1972). European fournal of Clinical and Biological Research, 17, 345 .

\section{MEDICAL MEMORANDA}

\section{Recovery from Profound Hypother- mia with Cardiac Arrest after Immersion}

\author{
E. DOMÍNGUEZ DE VILLOTA, G. BARAT, \\ P. PERAL, A. JUFFE, J. M. FERNANDEZ \\ DE MIGUEL, F. AVELLO
}

British Medical fournal, 1973, 4, 394-395

Hypothermia after prolonged immersion in cold water has been reported before (Kvittingen and Naess, 1963; Keatinge, 1965; Cahill, 1968). In the case we report here we believe that the low body temperature protected the brain against anoxic injury from a prolonged circulatory arrest.

\section{Case Report}

The patient, a boy aged 16 months, was brought to hospital at 5.40 p.m. on 6 February, 1973 after being found about eight minutes earlier, completely dressed, submerged face-down in a swimming pool at a nearby house. When rescued he had seemed dead and did not respond to mouth-to-mouth breathing carried out by his mother. She did not do cardiac massage. The air temperature at 6 a.m. had been $0.6^{\circ} \mathrm{C}$ and at 6 p.m. it was $11.4^{\circ} \mathrm{C}$.

On admission the child was apnoeic, pulseless, and cyanotic. His pupils were dilated, his abdomen bloated, and his body very cold to

\footnotetext{
Clinica Puerta de Hierro, Centro Nacional de Investigaciones Medico-Quirúrgicas de la Seguridad Social, San Martin de Medico-Quirúrgicas
Porres, Madrid 35

E. DOMINGUEZ DE VILLOTA, M.D., Associate Chief, Department of Anaesthesia and Intensive Care

G. BARAT, M.D., D.A.H., Associate Chief, Department of Anaesthesia and Intensive Care

P. PERAL, M.D., Associate Chief, Department of Anaesthesia and Intensive

A. JUFFÉ, M.D., Resident, Department of Cardiovascular Surgery

J. M. FERNANDEZ DE MIGUEL, M.D., Chief Clinician, Department of

Haemodynamics

F. AVELLO, M.D., Head of Department of Anaesthesia and Intensive Care
}

touch. Mouth-to-mouth breathing together with closed chest massage were instituted immediately. During endotracheal intubation he vomited large amounts and inhalation of gastric contents was suspected. Sodium bicarbonate $80 \mathrm{mEq} / \mathrm{l}$. was given intravenously and a drip infusion of $200 \mathrm{ml}$ of $1 / 6$ molar sodium bicarbonate was started. Asystole was replaced by ventricular fibrillation after intracardiac administration of epinephrine $1 \mathrm{mg}$. A D.C. shock of 200 watt seconds at 5.55 p.m. did not stop the fibrillation, but after a second shock five minutes later slow contractions of a supraventricular type were seen on the electrocardiogram. This was 30 minutes after the body had been taken from the water. No blood pressure could be recorded and norepinephrine $0.1 \mathrm{mg}$ in $50 \mathrm{ml}$ of $5 \%$ dextrose in water was administered. Positive-pressure ventilation with air and oxygen and external cardiac massage were maintained throughout resuscitation. No rales were heard in the lungs at any time. A blood sample obtained before intubation showed profound acidaemia (see table).

By 6.30 p.m. sinus rhythm was established with a pulse rate of $90 / \mathrm{min}$ and a systolic blood pressure of $90 \mathrm{~mm} \mathrm{Hg}$. The pupils were constricted and reacted to light. At 7.30 p.m. the rectal temperature was $27 \cdot 8^{\circ} \mathrm{C}$, the first accurate measurement obtained. Hypothermia persisted for seven hours. Twelve hours after admission the temperature was within the normal range (see chart). Spontaneous respiratory movements were noted at about 9.30 p.m., but the child remained comatose and unresponsive to painful stimuli. The pupils varied in size and responded sluggishly to light during the night. An $x$-ray film taken at 11.30 p.m. showed clear lung fields and a normal-sized heart. No free plasma haemoglobin was found. At 2 a.m. the serum sodium was 140 and serum chloride $107 \mathrm{mEq} / \mathrm{l}$. Urine glucose was positive $(+)$. The child moved spontaneously at about $4 \mathrm{a} . \mathrm{m}$. The rectal temperature was then above $35^{\circ} \mathrm{C}$. By 6 a.m. it had risen to $37.3^{\circ} \mathrm{C}$, and he was able to breathe efficiently by himself.

No neurological deficit was found on examination on the day after admission and an electroencephalogram was within normal limits. Other findings were: haemoglobin $10.6 \mathrm{~g} / 100 \mathrm{ml}$, serum sodium $138 \mathrm{mEq} / 1$., serum potassium $4 \cdot 1 \mathrm{mEq} / 1$., serum chloride $99 \mathrm{mEq} / \mathrm{l}$., blood urea $63 \mathrm{mg} / 100 \mathrm{ml}$, serum creatinine $0.9 \mathrm{mg} / 100 \mathrm{ml}$, urine osmolality $485 \mathrm{mOsm} / \mathrm{l}$., urine sodium $49 \mathrm{mEq} / \mathrm{l}$., and urine chloride $32 \mathrm{mEq} / \mathrm{l}$. The urea concentration in urine was $8.8 \mathrm{mg} / 100 \mathrm{ml}$ and the white cell count $16,600 / \mathrm{mm}^{3}$. Hyperthermia up to $38 \cdot 8^{\circ} \mathrm{C}$ was observed over the next 72 hours. The chest $x$-ray films remained clear. Subsequent progress was uneventful and the child was discharged after 14 days.

\section{Comment}

The hypothermia in this case was probably due to prolonged 